\title{
THE CHALLENGES OF INDONESIA AS A "QUINTESSENTIAL TRANSIT COUNTRY" FOR REFUGEES: CASES OF REFUGEES IN CITY OF PEKANBARU
}

\author{
Cifebrima Suyastri \\ International Relations Department, University Islam Riau \\ cifebrimasuyastri@soc.uir.ac.id \\ Rika Isnarti \\ International Relations Department, Pertamina University \\ rika.isnart@universitaspertamina.ac.id \\ Rendi Prayuda \\ International Relations Department, University Islam Riau \\ rendiprayuda@soc.uir.ac.id
}

\begin{abstract}
Indonesia is one of the Refugee Transit Countries and one of the largest in Asia. This situation also implies that Indonesia has other responsibilities to protect both its citizens and refugees. However, due to its position as a transit country, Indonesia, unlike final destination countries, does not have an obligation to protect refugees entirely. The purpose of this research is to analyze Indonesia's acceptance of refugees and the challenges it faces. The acceptance of refugees as a transit country and not a final destination for refugees will threaten Indonesia's economic, social, security and other sectors. The number of refugees in Indonesia and their continued detention is still increasing. This study utilizes the norm life cycle theory to determine the Indonesian reasons for accepting refugees. It collects information from focus group discussions or an in-depth interview with some of the NGOs in Pekanbaru, and library research, using qualitative method. Indonesia was found to be in the norm emergence stage and going to the norm cascade, although not entirely in the norm cascade phase. Within this theory, altruism and empathy are the dominant motives for the Indonesian reason to accept the refugees. In the case of the city of Pekanbaru, the challenges faced by Indonesia in dealing with refugees are a lack of service to refugees, particularly in terms of empowerment for the refugees, a high number of refugees imbalanced with detention facilities, and a lack of refugee handling due to the limitation of government policy.
\end{abstract}

Keywords: Indonesia, Refugees, quintessential transit country, Pekanbaru 


\section{Abstrak}

Indonesia merupakan salah satu negara transit pengungsi dan salah satu yang terbesar di Asia. Situasi ini juga mengimplikasikan bahwa Indonesia memiliki tanggung jawab lain untuk melindungi warga dan pengungsi. Namun karena posisinya sebagai negara transit, Indonesia tidak seperti negara tujuan akhir, tidak memiliki kewajiban untuk melindungi pengungsi sepenuhnya. Tujuan penelitian ini adalah menganalisis alasan Indonesia menerima pengungsi dan tantangan yang dihadapinya. Penerimaan pengungsi sebagai negara transit dan bukan tujuan akhir pengungsi akan mengancam sektor ekonomi, sosial, keamanan dan sektor lainnya di Indonesia. Meski demikian, jumlah pengungsi di Indonesia dan penahanan lanjutannya masih terus meningkat. Untuk mengetahui alasan Indonesia menerima pengungsi, penelitian ini menggunakan teori norm life cycle. Penelitian ini mengumpulkan informasi dari diskusi kelompok terfokus atau wawancara mendalam dengan beberapa LSM di Pekanbaru, dan penelitian studi pustaka, dengan menggunakan metode kualitatif. Indonesia ditemukan berada pada tahap norm emergence dan menuju tahap norm cascade, meskipun belum sepenuhnya berada pada tahap norm cascade. Dalam teori ini, altruisme dan empati menjadi motif dominan alasan Indonesia menerima pengungsi. Dalam kasus Kota Pekanbaru, tantangan yang dihadapi Indonesia dalam menangani pengungsi adalah kurangnya pelayanan kepada pengungsi, khususnya dalam hal pemberdayaan bagi pengungsi, tingginya jumlah pengungsi yang tidak seimbang dengan fasilitas di detensi, dan minimnya pengungsi. penanganan karena keterbatasan kebijakan pemerintah.

Kata kunci: Indonesia, Pengungsi, Negara Transit, Pekanbaru 


\section{Introduction}

Indonesia is one of a quintessential transit country.Hugo, Tan, \& Napitupulu, (2017) defines the quintessential country as a country occupy a position to accommodate refugees temporarily before reaching the final destination country. The presence of Indonesia as a quintessential transit country is quite significant. It is indicated by the increasing number of refugees every year. The number of refugees has increased by up to $30 \%$ from 2014 to 2015 (UN Refugee Agency (UNHCR), 2015). In the following years, the upward trend is still happening and showing no signs of decreasing. the UNHCR also publishes that there are three significant countries as countries of origin of refugees in Indonesia. They are Afghanistan 55\%, Somalia 10\%, and Iraq 7\% with currently 13743 refugees and asylum seekers situated in Indonesia (UNHCR Indonesia, 2020).

In International Relations, the topic of refugees is varied. International Relations scholars analyse how the existence of refugees influence states relations and states response towards it. This condition has made Indonesia traversed by refugees so that this also has implications for increasing the number of refugees in Indonesia.
The presence of a large number of refugees will certainly raise demographic or population problems and are related to economic-social conflicts. This condition also happened in Pekanbaru. Various problems have arisen and have often resulted in unrest that has resulted in public reporting to the Pekanbaru City government.

Some problems exist from refugees in Pekanbaru, such as lack of education access for immigrant children, the uncertainty of working possibilities for adults, and uncertainty of the amount of time they spend in Indonesia before departing to a final destination country Australia. Most Indonesian formal schools are delivered their knowledge in Indonesia rather than other languages. Bringing immigrant children to Indonesian formal school will be an obstacle for the children due to language barriers and the teacher delivering the material. Further, there is no regulation in Indonesia that allowing refugees children to study in Indonesia formal school. In some cities, Indonesia has a detention centre under the ministry of law and human rights called Rumah Detensi Migrasi (Rudenim). Here, refugees can access basic needs, such as shelter, protection, and safeguard. However, due to Indonesia's extended stay, they will need 
more allowance to survive before reaching their destination. However, finding refugees' jobs is not that easy, language barriers, skills, jealousness from local people, and lack of regulation from the government about giving jobs to refugees will be set of obstacles faced by refugees.

Further, social despise from local can trigger further conflict. Local people sometimes think refugees are much more being paid attention from government than them. They can get to fulfil their basic needs without having to go to work and obtain many aids. In addition, the local government has no obligation to accept refugees but still sometimes willingly accept them (Hartati, 2016).

From a regulation perspective, Indonesia has not signed the 1951 Convention relating to the Status of Refugees or its 1967 Protocol. It means Indonesia cannot determine the status of the refugees. Therefore, this responsibility will be carried by UNHCR in Indonesia. However, the location of the shelter is in Indonesia sovereignty. Direct or indirect this situation still influence Indonesia condition. Indonesia is not the party signed the protocol; however, it has an obligation for the refugees due to the state location of detention, and still, Indonesia has to protect its people.
From this background, this research seeks Indonesia motives to accept still the refugees and asylum seekers and the challenges it faces from local where detention located. Pekanbaru is chosen as a research location as in this area one of Indonesia Rudenim is located and one of UNHCR operation area in Indonesia. Further, in sumatera there are three detention centres that located in Medan, Tanjung Pinang, and Pekanbaru. Geographically, sumatera could be seen as the nearest location for refugees and asylum seekers to be reached if they depart from middle east or south asia as dominant refugees in detention centres in Sumatera.

\section{Literature Review}

From states receiving perspective, refugees bring some threats. However, states have different perspectives in accepting refugees (Eka Nizmi, 2016). Lack of citizen can positively impact being economical from refugees because there is an additional labour force. However, some harmful threats are also facing states from refugees. Aniol's research in Kicinger, (2004) explains that international migration can be considered a threat if it occurs massively and cannot be controlled. If international migration continues, it will impact racial violence and xenophobia, which can lead to threats to national 
security (O’neill, 2006). In addition, international migration brings threats such as physical threats that refugees can pose to society or the state and Economic threat due to competition over job opportunities with local. Further, social threats to society could happen from international migrant such as crisis identity language barriers, violate social system, mixing religious practices, the potential to terrorism and human trafficking (Deo, 2014; Innes, 2010; Lee, 2018; Seidman-Zager, 2010).

In this research, the norm life cycle theory is employed. Finnemore \& Sikkink, (1998) defines the norm as a standard of appropriate behaviour for actors with a given identity. In the norm, there is a set of appropriate or proper behaviour by reference to society's judgemental. Norm has to be practised by particular society before adopting by others, here, it is essential to know how the norm emerges, the process of its influence, and the condition the norm should be applied. These conditions are known as the norm life cycle.

Norm may influence in three stages, namely norm emergence, norm cascade, and internalisation. Between norm emergence and norm cascade, there is a tipping point - a situation where actors will receive the norm or not. In the norm emergence process, there are norm entrepreneurs that could be international or transnational actors responsible for persuading the mass of states to embrace the new norm (Sundstrom, 2005). Second stage norm cascade is when the norm has been practised by many and states imitate it. Many states' motivations imitate the norm, like leader self-esteem, international legitimation, international pressure, and more. If states are practising the norm continually and no objection from the domestic, states will come to the tipping point phase, a situation where the new norm should be adopted or not. If the norm cannot be applied and rejected from the domestic or others, it will no longer be practised and could start over from the emergence stage. However, if the norm practice accepts domestically and applies without no objection, it will become a habit and taken for granted sooner or later. It will be part of the state behaviours and characteristics. When states come into this process, it means it is in the internalisation process.

Norm emergence could be a success if there are norm entrepreneurs that are an organisation that entrepreneurs act. There are some norm entrepreneurs' motives in promoting the norm; those are empathy, altruism and ideational (Finnemore \& Sikkink, 1998). Empathy means the norm entrepreneurs have an interest in other own 
sakes. Altruism is when norm entrepreneurs do some actions for the other party's benefit, although it could harm the norm entrepreneurs. Ideational means norm entrepreneurs do something because they believe in what is ideal and believe in the good value it will obtain from doing norm promotion.

To bring states to norm emergence, norm entrepreneurs have to promote or socialise in persuasion. Norm entrepreneurs should frame the norm as appropriate standard behaviour and should be applied by states. Falling to do so, where norm entrepreneur cannot framing it to be accepting as standard behaviour or doing socialisation by coercion will make the process fail. States will not have the sense to imitate it and make it a proper behaviour.

To go to the next stage, states have pass tipping point or threshold of the norm life cycle, in this situation states believe it should implement the norm due to its society where it belongs and ready to institutionalise the norm by adopting the rule, signed the policy or others.

If states pass the threshold, it will come to the second stage, norm cascade, in this stages, states imitate the norm but do not fully take in for granted or as part of the identity. States, international organisation, and states networks are needed to promote the norm to make state concise with the norm actions. Legitimacy, state reputation and self-esteem are states motivation to imitate the norm. In the mechanism process, institutionalisations are needed, such as states have a set of laws regarding the norm implied and sometimes domestic will remain states' behaviour to be concise with norm actors. People can do a demonstration to the government as a reminder to act as a norm that accepted.

Further, here states cannot take backward actions as states image is at stake. It has to create a good image to make a place for its interaction internationally as states tend to make networks with other states with the same perception.

The next stage is the internalisation. In this stage, the states take the norm as a habit. It is no longer other actors to promote or socialise it or remind it, as the norm has become the part of the state's identity. In this stage, states will make some bureaucracy and law regarding the norm, states practice in this norm can be found in domestic life, and practice is a habit not because others watch them. In this stage, states will do two significant actions, implement the norm as daily habit and identity, where It belongs and tries to become norm entrepreneurs for other states to adopt the norm. Below are the stage of the norm from Finnemore and Sikkink. 
Table 1. Stage of Norm

\begin{tabular}{|l|l|l|l|}
\hline & $\begin{array}{l}\text { Norm } \\
\text { emergenc } \\
\text { e }\end{array}$ & $\begin{array}{l}\text { Norm } \\
\text { cascade }\end{array}$ & $\begin{array}{l}\text { internaliz } \\
\text { ation }\end{array}$ \\
\hline Actors & $\begin{array}{l}\text { Organiza } \\
\text { tional } \\
\text { platform }\end{array}$ & $\begin{array}{l}\text { States, } \\
\text { international } \\
\text { organization } \\
\text { s, network }\end{array}$ & $\begin{array}{l}\text { Law,profes } \\
\text { sions, } \\
\text { bureaucrac } \\
\text { y }\end{array}$ \\
\hline Motives & $\begin{array}{l}\text { Altruism, } \\
\text { emphaty, } \\
\text { ideatonal } \\
\text { commitm } \\
\text { ent }\end{array}$ & $\begin{array}{l}\text { Legitimacy, } \\
\text { reputation, } \\
\text { esteem }\end{array}$ & conformity \\
\hline $\begin{array}{l}\text { Mechani } \\
\text { sm }\end{array}$ & $\begin{array}{l}\text { persuasio } \\
\text { n }\end{array}$ & $\begin{array}{l}\text { Socialization } \\
\text { institutionali } \\
\text { zation, } \\
\text { demonstratio } \\
\text { n }\end{array}$ & $\begin{array}{l}\text { Habit, } \\
\text { institutiona } \\
\text { lization }\end{array}$ \\
\hline
\end{tabular}

Source : Finnemore and Sikkink International Norm Dynamics and Political Change, 1998

\section{Research Methods}

This study uses a qualitative method. Which means this research is looking for meaning from the data collection carried out. Literature review is the primary data collection-also, problem mapping by conducting discussions with UNHCR and IOM as well as with research centres for refugees. Research related to the government's response in responding to an issue or problem will be carried out using qualitative research methods, qualitative research methods are chosen because qualitative research methods aim to obtain a complete picture of something according to the human perspective being studied.

This method is related to ideas, perceptions, opinions, or beliefs of the person being studied; all of which cannot be measured in numbers, because this study aims to determine the reasons for the actors to take action and the interests of the actors.

In doing data analysis, this research goes through 5 stages. The first stage is a needs analysis, namely by reviewing relevant literature on the topic, so that author can find out what methods to do, and in the next stage is to realize the method by collecting data and information in the form of Focus Group Discussions together with relevant sources with the topic and continued on the results and discussion so that the author finally comes to suggestions and conclusions. The following is a research flow chart.

\section{Figure 1. Research flow chart}
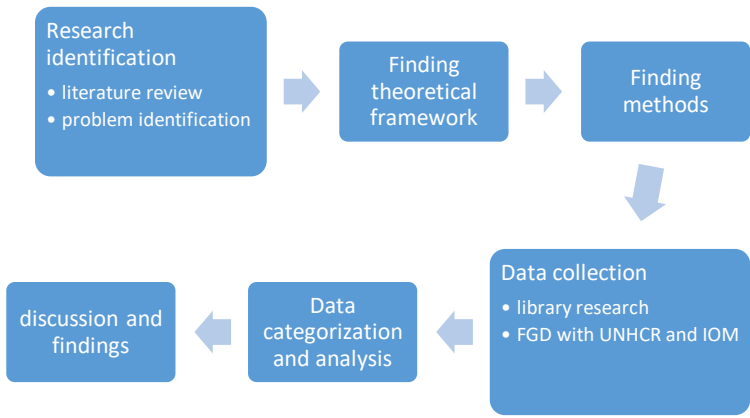

\section{Discussion and Result}

Indonesia as transit country

Graham \& Poku (2005) defines

refugees and asylum seekers as Those who 
leave their home countries to escape the dangers of either conflict, persecution or natural disasters. This group is one of the largest groups of migrants in the world and the most difficult to deal with. Meanwhile setters is those enter a country intending to reside permanently. Examples of countries that are the destination for settlers are the United States, New Zealand, Canada and Australia. Refugees and asylum seekers different from illegal migrant, by the definition the second is those who enter a country without a valid permit, or exceed the agreed limit of residence permit.

Legally Indonesia has not yet ratified the 1951 Convention related to the Condition of Refugees or the 1967 Protocol. It means Indonesia has no obligation for the protection and determination of the refugees status. This obligation is taking over by UNHCR in Indonesia. This organization decides whether the refugees granted to the third country or not. However, Indonesia has Rudenim as for the refugees to temporarily stay in Indonesia due to incomplete documents, miss administration, asylum seekers, and soon. There are thirteen Rudenim that spread around Indonesia located in Tanjung Pinang, Pekanbaru, Jakarta, Kupang, Denpasar, Balikpapan, Makasar, Jayapura, Manado, Medan, Pontianak, Semarang and Surabaya.
Data from UNHCR states that there are 13515 persons in Indonesia as refugees and asylum seekers and dominantly from Afghanistan, Somalia, Iraq, and Myanmar (UNHCR, 2020). In the province of Riau there two Rudenim, one located in Tanjung Pinang and another located in Pekanbaru. The city of Pekanbaru, based on data collection, found that there are around 968 refugees and asylum seekers under Rudenim Pekanbaru supervision. While the Rudenim in Pekanbaru cannot accommodate all of them, the city of Pekanbaru employs community to tackle problem-related to this overcapacity of the refugees and asylum seekers. The refugees are sheltered in community houses or hotel managed by a community. Until this research conducted, there are eight community shelters in Pekanbaru for the refugees namely Wisma Indah, Hotel Satria, Wisma D’Cops, Hotel Rina, Wisma Novri, Wisma Siak Resort, Wisma Fanel, wisma Tasqya. IOM helps them for this community shelters.

Nevertheless, those community shelters are under the supervision of Rudenim Pekanbaru. Like glance of refugees number in Indonesia, the number of refugees situated in Pekanbaru also dominant by Afghanistan. It is also found that $80 \%$ of refugees in Pekanbaru are from Afghanistan, 5\% from Palestine, and 4\% 
from Myanmar. While the rest are varied worldwide with a percentage of less than $3 \%$, they are Somalia, Iraq, Iran, and Pakistan.

As stated, Indonesia is transit country, the refugees or asylum seekers chose to transit to Indonesia due to its location close to Australia as destination country and relatively cheap compared to Canada or other European countries (Human Rights Watch, 2012). Indonesia is not chosen as destination country because it does not meet a wealthy country's criteria, democratic, friendly, human rights protection, and more (Missbach, 2017).

UNHCR decides refugees' determination status in Indonesia. Meanwhile, the Ministry of Law and Human Rights, and Directorate - General Immigration of Indonesia only responsible for finding refugees in Indonesian territory, the Indonesian government placed and supervised them in Rudenim. Meanwhile, their final status, whether granted to the third country, returned to the country of origin, or moved to other shelters, will collaborate with UNHCR and other institutions like IOM (Wagiman, 2012). It is supported by Presidential Regulation on the Handling of Refugees released by Indonesian president in 2016 to regulate the process for the detection, shelter and safeguarding of refugees and asylum seekers in Indonesia. Below are diagram process of refugees reporting in Indonesia untul granted.

Figure 2. Process of Registration of Asylum Seekers and Refugees in Indonesia

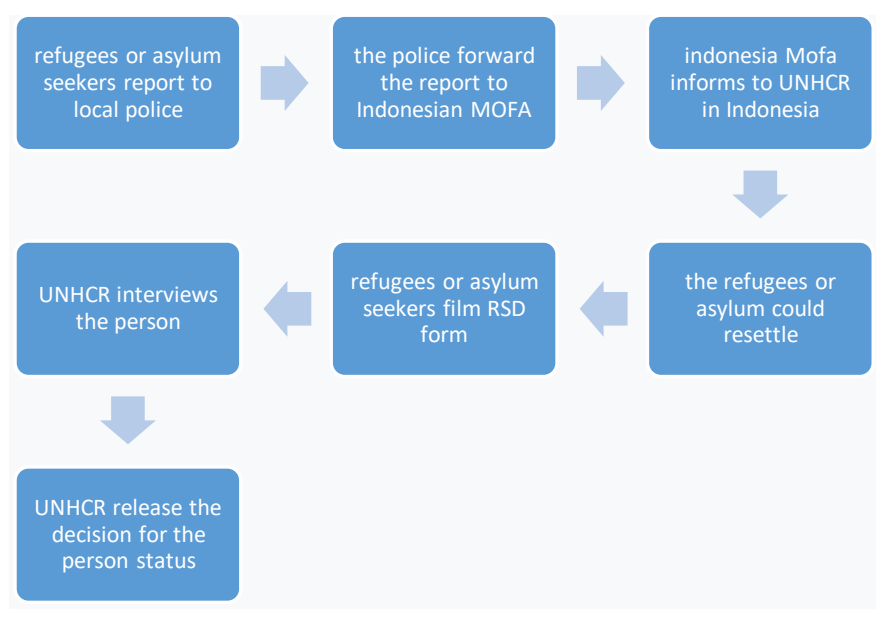

The Indonesian Motives for The Admission of Refugees from The Norm Life Cycle

Although Indonesia did not ratify the 1951 Geneva convention and the 1967 Additional Protocol on refugees, it is believed that Indonesia is accepting refugees because of states' perception of human protection as states' responsibility. States has a responsibility towards its citizens and foreigners who reside in their country by giving protection and safeguards whether individuals or minority groups (Isnarti, 2018). Of course, states must be distinguished between individual rights and 
collective rights and foreign and citizen rights (Græger \& Lindgren, 2018).

Christopher (2007) argues that state responsibility arises from acts against or violates international law. These actions can be in the form of delictual liability or for the occurrence of a breach of the agreement. Shaw \& Jennings (2008) believes that two primary factors cause the emergence of state responsibility. First, there are international obligations that apply between the parties. Second, there is an action or silence that violates obligations. Crawford (2002) is even more emphatic that state responsibility arises because of any act or actions against the law. According to him, illegal acts violate an international agreement or violate a legal obligation. Also, states actions that violate an agreement and state actions that cause harm to the state or other citizens (Suyastri, 2020).

Analyzing this problem using norm life cycle, Indonesia stage is in norm emergence, Indonesia is being socialized and promoted about the refugee's protection by the norm entrepreneurs, in this case, is UNHCR and IOM. These norm entrepreneurs motives to promote the norm in Indonesia is ideational as the organization mission is to empower and protect the refugees. On the other hand,
Indonesia motives in norm emergence by following the norm is altruism and empathy. In altruism, Indonesia tries to fulfil the needs of the refugees also at the same times. It gives drawbacks like posing some threats to Indonesia. In empathy, Indonesia is known as a country concerning human rights and applies its practice. Indonesia accepting refugees because of the sympathy to their problem and tries to be a good international society where Indonesia belongs to states that implement human rights.

Indonesia is not yet at the tipping point or threshold. Increasing threats from refugees that directly threaten citizens can cause Indonesia to stop accepting refugees and give protection and safeguard. The pressure can come from the citizens or the government. Another indicator is no international rule implement by Indonesia in handling the refugees and asylum seekers. The norm entrepreneurs in Indonesia succeed in framing the issue as an important norm that Indonesia should apply. This situation indicated by the number of the detention centre in Indonesia and empowers society to refugees to fulfil their rights such as education, economic and others. However, Indonesia better imitates the norm by releasing president regulation in handling refugees and asylum 
seekers in Indonesia. Another indicator of Indonesia's success in norm emergence is that Indonesia is in the problem's critical state. States will accept the norm and admit its existence as essential because of states condition. The more critical and related the states situation and condition to a norm, the easier they accept it. Indonesia's high number of refugees from year to year makes Indonesia more facing the problem and easier to accept the norm of protecting the refugees. However, while the number of refugees is low states also will be longer to accept the norm. This situation also occurs in local government, City of Pekanbaru government will be more adaptive to refugees and allocate some efforts to solve the issue as it directly imposes their society. Therefore, the city of Pekanbaru has adopted and implemented some policies about the refugee's problems. The situation will be different from the neighbourhood city that indirectly faces refugees problem. City of Padang or Jambi's city will not take much effort to solve the refugee's problem as they do not impose the problems.

Indonesia has support condition to be able in the stage of cascade. To be in cascades stage, states imitate the norm because more countries adopt the norm rapidly, and there is international socialization like a multilateral collaboration by giving sanction and incentives to states adopt the norm. In Indonesia, neighbourhood countries like Malaysia, Thailand, and Vietnam also accept the refugees and show good practice in handling them. Little by little, this situation will trigger Indonesia to work together with them in handling refugees. In term of sanction and initiatives, Indonesia receives come fundings from international organization to manage the refugees. Together with Australia, Indonesia often does the patrol to locate the refugees and sometimes receive some of Australia's fundings to resettle the refugees in Indonesia. Conformity and esteem are two Indonesian motive to be in norm cascade stage. The conformity means Indonesia would like to show to international society and its peers that Indonesia also belongs to the country can adopt human rights and respect it by providing good practice in handling refugees in giving protection. In term of esteem, we can analyze it from the local government perspective, each city or province in Indonesia has different problems to be handled. The city of Pekanbaru handling refugees will make the city image improve, especially when it shows that the city management is handling refugees by collaborating with locals that are different from other cities having foreign detention in Indonesia. Although 
the city of Pekanbaru faces with overcapacity of refugees and asylum seekers, imitate the norm of protecting and empowering the community will make it a good practice and source of learning in handling refugees for other cities.

The Challenges of Indonesia as Quintessential Transit Country

Indonesia faces many challenges in handling refugees as a transit country. On the one hand, Indonesia should protect them as its position as a transit country. On the other hand, Indonesia cannot fully protect and provide their full needs as an absence of Indonesia ratification of the international convention in handling refugees. The first challenges are fulfilling refugees' basic rights such as education, economy, finding jobs, and others. There is a high number of children as refugees in Indonesia that spread in all of Indonesia detention. These children need an education. While they stay for long periods in Indonesia, they cannot fulfil the education rights in Indonesia. There is no specific regulation in Indonesia, allowing children refugees to get a formal education from Indonesia's formal school. In the case of Pekanbaru, the regional office of education often presents the program for the children to obtain the formal education, however, lack of the regulation for them, the Rudenim cannot allow them to go to formal school and get daily education like other children. Therefore, we need specific regulation, sanction, and incentive to regulate the refugees' basic rights in Indonesia.

Second challenges are long procedure. UNHCR Indonesia decides the refugee's determination status in Indonesia. To obtain this, the refugees have to follow a set of procedures until their final decision about their status released. This process takes time. To fulfil the refugees' determination status form to get interview schedules, it will usually take two years. Meanwhile, there is a high number of refugees in Indonesia waiting for the decision.

Third challenges are overcapacity. The number of detention centre in Indonesia is limited; it only has thirteen locations and accommodates many refugees. The distribution of the detention is not also the same from island to island. Some islands could have many locations for detention, while others could only have one. Sometimes the capacity could be doubled or tripled. This situation happens because the number of refugees in Indonesia is many, and their stay in Indonesia is in a long period, although they do not expect so. The refugees in Indonesia could stay for six years or be more before receiving the final decision from UNHCR about their status. 
The refugees can ask IOM to move them from detention to others. The IOM then can deliver their willingness to the Rudenim. However, the problem still the same, overcapacity; therefore, they still face the same situation. Sometimes some of the detention centres have to reject the refugees due to the capacity; if not, it will give officers a problem in supervising them. This situation also happens in Pekanbaru, although there are two detentions centre in Riau Province, the capacity of detention in Pekanbaru is also overcapacity. As a result, the city government empower the community as shelters for the refugees. The city of Pekanbaru empowers other seven locations that mention above as shelters. Supervise under the regional office of Pekanbaru immigration in this community service; the community takes part in handling the refugees. The local community's situation does not mean they free to go anywhere they want, still the refugees have obtained the permit from the Rudenim if they want to do an activity outside the detention centre where they are settled.

\section{Conclusion}

Refugees and asylum seekers are one of the phenomena in IR recently. States reaction to this issue could vary. Indonesia is one of the transit countries in Asia by receiving many refugees and asylum seekers worldwide to continue to a third or final destination country like Australia. However, Indonesia does not ratify refugees protocol make Indonesia situation accepting refugees become complex. The existence of refugees in Indonesia could bring many threats, such as economic, social, cultural and more. However, Indonesia still accepts refugees. Indonesia position in norm emergence can be seen as Indonesia reasons to accept the refugees. Indonesia is being socialized by an international organization like IOM and UNHCR about protecting refugees and asylum seekers. As norm entrepreneurs, these international organizations motivate to promote the norm to Indonesia because of ideational of refugees and asylum seekers' rights to get protection and safeguard anywhere. Further, Indonesia is being promoted by the implementation of human rights for all human beings. Indonesia is not in the stage of norm cascade indicated by lack of government regulation as legitimacy. However, Indonesia wants to build a better reputation as a country familiar with human rights as a motive.

Indonesia's challenges in handling refugees, first limited regulation or policy 
in handling these refugees, make the fulfilment of refugees' rights in Indonesia cannot be implemented. For example, there is no regulation for children refugees to get education from the formal school in Indonesia. It makes them cannot obtain formal education in Indonesia. Second, the process to determine the refugees' status handled by UNHCR in Indonesia takes a long time. As a result, the refugees have to stay long in Indonesia without uncertainty. The number of detention centres in Indonesia is also limited and overcapacity. As a result, in the city of Pekanbaru, refugees and asylum seekers must stay in community centres based on supervision from the directorate general of Immigration in Indonesia.

\section{References}

Christopher, E. (2007). Many Middle Passages: Forced Migration and the Making of the Modern World. (1st ed..).

Crawford, J. (2002). The ILC's Articles on Responsibility of States for Internationally Wrongful Acts: A Retrospect. Source: The American Journal of International Law, 96(4), 874-890.

Deo, R. (2014). The Securitization Of Asylum Seekers In Canadian Political.
Ryerson University. Retrieved from https://digital.library.ryerson.ca/island ora/object/RULA\%3A3293

Eka Nizmi, Y. (2016). Globalisasi, Imigrasi, Dan Keamanan Identitas Eropa. Jurnal Tapis: Jurnal Teropong Aspirasi Politik Islam (Vol. 12). https://doi.org/10.24042/TPS.V12I1.8 32

Finnemore, M., \& Sikkink, K. (1998). International Norm Dynamics and Political Change. International Organization, 52(4), 887-917. https://doi.org/10.1162/00208189855 0789

Græger, N., \& Lindgren, W. Y. (2018). The Duty of Care for Citizens Abroad: Security and Responsibility in the In Amenas and Fukushima Crises. The Hague Journal of Diplomacy, 13(2), 188-210.

https://doi.org/https://doi.org/10.1163 /1871191X-11302009

Graham, D. T., \& Poku, N. K. (2005). Migration, globalisation and human security. Migration, Globalisation and Human Security. Taylor and Francis Inc.

https://doi.org/10.4324/97802039806 75

Hartati, S. (2016). Sekuritisasi Pengungsi Rohingya Di Indonesia. Universitas 
Gadjah Mada.

Hugo, G., Tan, G., \& Napitupulu, C. J. (2017). Indonesia as a transit country in irregular migration to Australia. In A Long Way to Go: Irregular Migration Patterns, Processes, Drivers and Decision-making (pp. 167-196). ANU Press. Retrieved from http://www.jstor.org/stable/j.ctt20krx xh. 15

Human Rights Watch. (2012). World Report 2012: Indonesia. Retrieved September 23, 2020, from https://www.hrw.org/worldreport/2012/countrychapters/indonesia

Innes, A. J. (2010). When the Threatened Become the Threat: The Construction of Asylum Seekers in British Media Narratives. International Relations, 24(4), 456-477. https://doi.org/10.1177/00471178103 85882

Isnarti, R. (2018). Humanitarian Intervention from Constructivist Perspective: CaseStudy of China Peace Keeping Operation in Darfur. AEGIS: Journal of International Relations, 2(2). https://doi.org/10.33021/aegis.v2i2.42 5

Kicinger, A. (2004). International
Migration As A Non Traditional Security Threat And The Eu Responses To This Phenomenon. warsaw. Retrieved from www.cefmr.pan.pl Lee, A. (2018). Forced Migrants, Media, and Securitization: Making Sense of the Changing Representations of Transit Asylum Seekers in Indonesian Print Media. JAS (Journal of ASEAN Studies), $\quad 5(2), \quad 75$. https://doi.org/10.21512/jas.v5i2.392 3

Missbach, A. (2017). Accommodating asylum seekers and refugees in Indonesia: From immigration detention to containment in "alternatives to detention." Refuge, 33(2), 32-44. https://doi.org/10.7202/1043061ar

O'neill, R. E. (2006). Defence Studies The European Union and Migration: Security versus Identity? https://doi.org/10.1080/14702430601 060149

Seidman-Zager, J. (2010). The Securitization of Asylum: Protecting UK Residents. UK: Refugee Studies Centre.

Shaw, M. N., \& Jennings, R. (2008). International Law (6th ed.). New York: Cambridge University Press. Retrieved from www.cambridge.org 


\section{MANDALA:}

Sundstrom, L. M. I. (2005). Foreign assistance, international norms, and NGO development: Lessons from the Russian campaign. International Organization, 59(2), 419-449. https://doi.org/10.1017/S0020818305 050149

Suyastri, C. (2020). Pendekatan Hubungan Internasional Terhadap Perlindungan Pengungsi : Menjelaskan Inisiatif Kebijakan Pemerintah Indonesia dan UNHCR. Frequency of International Relations (FETRIAN), 2(1), 88-113. https://doi.org/10.25077/fetrian.2.1.88 $-113.2020$

UNHCR. (2020). Indonesia fact sheet april 2020. Retrieved from www.unhcr.org2

Wagiman. (2012). Hukum Pengungsi Internasional. Yogyakarta: sinar grafika. 